\title{
HABITAT, SEED DORMANCY, AND ALLOZYME VARIATION OF THE RARE ENDEMIC Phacelia cookei (BORAGINACEAE)
}

\author{
A Thesis \\ Presented \\ to the Faculty of \\ California State University, Chico \\ In Partial Fulfillment \\ of the Requirements for the Degree \\ Master of Science \\ in \\ Botany \\ by \\ Melissa E. Patterson
}

Fall 2010 
HABITAT, SEED DORMANCY, AND ALLOZYME VARIATION OF

THE RARE ENDEMIC Phacelia cookei (BORAGINACEAE)

\author{
A Thesis \\ by
}

Melissa E. Patterson

Fall 2010

APPROVED BY THE DEAN OF GRADUATE STUDIES

AND VICE PROVOST FOR RESEARCH:

Katie Milo, Ed.D.

APPROVED BY THE GRADUATE ADVISORY COMMITTEE:

Christopher Ivey, Ph.D., Chair

Kristina A. Schierenbeck, Ph.D.

Adrienne Edwards, Ph.D.

Colleen A. Hatfield, Ph.D. 


\section{ACKNOWLEDGMENTS}

I would like to thank my committee, Dr. Chris Ivey, Dr. Adrienne Edwards, Dr. Kristina Schierenbeck, and Dr. Colleen Hatfield for their guidance, support, and comments on this study, which would not have been possible without them. I would also like to thank Tara Forbis, Jamie Roice, and Bob Blank at the Exotic and Invasive Weeds Research Unit in Reno, Nevada for conducting the germination study and soil analysis. Erin Esp at University of California- Davis for her help with the statistical analysis. I would like to thank Nicole Habecker, Allyson Pokrzywinski, and Ryan Johnson for their help with fieldwork. I would also like to thank my family and friends for their love, support, and editing that kept me going when I wanted to give up. I received support through the CSU-Chico Graduate Equity Fellowship. This study was funded by a grant from the U.S. Forest Service. 


\section{TABLE OF CONTENTS}

PAGE

Acknowledgments ........................................................................................... iii

List of Tables ..................................................................................................

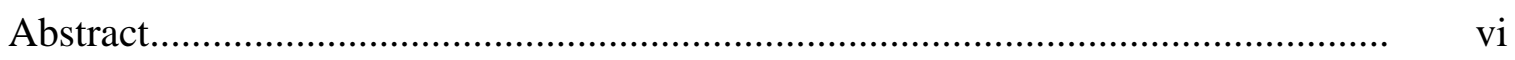

\section{CHAPTER}

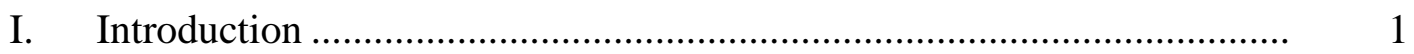

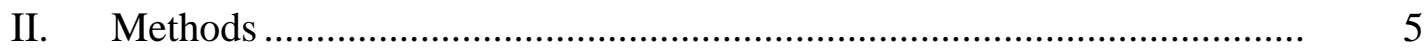

Species Description ................................................................... 5

Habitat Survey ……………………………………………..... 6

Germination Methods ............................................................... 9

Isozyme Methods......................................................................... 13

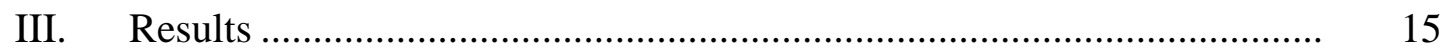

Habitat Surveys ……………………………………................ 15

Germination Results ................................................................ 20

Allozyme Variation ................................................................... 22

IV. Discussion................................................................................... 25

Habitat ..................................................................... 25

Germination...................................................................... 26

Allozyme Variation ................................................................. 27

V. Conclusion ......................................................................................

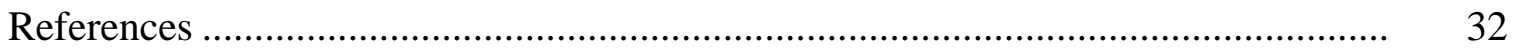




\section{LIST OF TABLES}

TABLE

PAGE

1. Site Locations and Site Categorization for a Survey of

Phacelia cookei Habitat in Siskiyou County, California,

USA, August 2009 .

2. Treatments Applied to Phacelia cookei Seeds in Tests to Break

Dormancy (“Germination Experiment 1” see Methods)

3. Treatments Applied to Phacelia cookei Seeds in Tests to Break

Dormancy

4. Percentage Cover of Plants Present at Sites Surveyed in a Study

Characterizing Habitat of Phacelia cookei.

5. Mean (SD) Responses from Soil Analyses Conducted During a

Survey of Habitat of Phacelia cookei...

6. Mean (SD) Percentage Germination of Phacelia cookei Seeds in a Test of Dormancy Cues ("Germination Experiment 1" See Methods).....

7. Mean (SD) Percentage Germination of Phacelia cookei Seeds in a Test of Dormancy Cues ("Germination Experiment 2" See Methods).

8. Allele Frequencies at Two Variable Isozyme Loci in Three Populations of Phacelia cookei

9. Genetic Diversity for Two Polymorphic Allozyme Loci in Three Phacelia cookei Populations.

10. The Relationship of Geographical Range to Allozyme Variability 


\author{
ABSTRACT \\ HABITAT, SEED DORMANCY, AND ALLOZYME VARIATION OF \\ THE RARE ENDEMIC Phacelia cookei (BORAGINACEAE) \\ by \\ Melissa E. Patterson \\ Master of Science in Botany \\ California State University, Chico
}

Fall 2010

Experimental studies of rare species are the most effective way to create management strategies to conserve species and prevent further decline and extinction. We conducted habitat surveys, germination, and population genetic surveys to inform management priorities for Phacelia cookei Constance \& Heckard (Boraginaceae), a diminutive annual herb only found within a three-mile radius near Mt. Shasta, California, and it is rare within that geographical range. Habitat surveys included a rapid vegetation assessment, soil samples, and assessment of ground cover. We found no significant differences among site category in soil types. An associated species list was created, and the most closely associated species was Nama densa A. Gray, which was found at four sites where P. cookei was present. We tested the effects of afterripening, scarification, stratification, and variable germination temperatures on breaking seed dormancy. Seed 
viability by tetrazolium tests ranged between $89 \%$ and $93 \%$, but the highest germination from any treatment combination was $38.9 \%$ after adjusting for seed viability. We resolved 19 putative allozyme loci, only two of which were polymorphic. This species had low genetic diversity within and among the three large sampled populations when compared to other endemic species with similar mating systems, and this may ultimately be an important challenge for maintaining viable populations of the species. Management plans should consider additional studies to explore the feasibility of restoring populations in suitable locations by sowing seeds collected from existing populations is suitable habitat. 


\section{CHAPTER I}

\section{INTRODUCTION}

Rare plants are an important component of biologically diverse ecosystems. Rare species can be widespread but infrequent throughout their distribution or have a very narrow geographical range with varying abundance; the latter are considered an endemic species. Narrow endemism often appears to be the result of adaptation to environments that are geographically restricted (Mason 1946). Endemic species with few individuals and/or populations are often especially susceptible to extinction due to their low numbers as well as their habitat specificity. Biodiversity hotspots are areas that have high concentrations of endemic species that are experiencing habitat loss (Myers et al. 2000).

The California Floristic Providence is considered a biodiversity hotspot, containing $0.07 \%$ of the world's endemic plant species (Myers et al. 2000). Global biodiversity is currently in a state of decline with multiple threats working synergistically to cause extinction (Brook et al. 2008). Habitat loss, invasion of non-native species, pollution, disease, overexploitation and climate change, individually or in combination, are the biggest threats to biodiversity (Wilcove et al. 1998; Higgins et al. 1999; Van Vurren et al. 2006). Conservation measures often need to address multiple threats to rare species to prevent extinction (Brook et al. 2008).

Interactions between plants in a community, biotic factors, and abiotic stress can be important in determining community structure and species survival (Pugnaire and Luque 
2001; Reynolds et al. 2003; Callaway and Walker 1997). A coarse-scale environmental component that can limit plant distribution is soil; edaphic endemism is a term commonly used to describe plants with limited distribution due to specific soil requirements (Mason 1946) and is well documented in several rare species (Kruckeberg 1954; Fiedler 1985; Cowling et al. 1994). Conservation programs, for example, have used disturbance methods such as fire or soil disturbance to manage rare species (Preston and Whitehouse 1986; Hobbs and Huenneke 1992; Pendergrass et al. 1999). Studies have generally shown intermediate levels of disturbance yield greatest species diversity, and diverse plant communities are more likely to support rare species (Grime 1973; Connell 1978; Myers et al. 2000). When evaluating a single species it is important to consider its response to the timing and type of disturbance in order to discourage establishment of non-native species, which can potentially out-compete and displace native and or rare species (Hobbs and Huennke 1992; McIntyre and Lavorel 1994; Wilcove et al. 1998; Huston 2004).

Identifying appropriate germination cues, such as cold stratification, scarification, afterripening, and specific temperature cycles can determine the feasibility of reintroduction of seeds from rare plants into uncolonized habitats in the field (Cochrane et al. 2002). Germination cues thus identified could be used to predict germination time in the field based on local weather patterns. Germination rates are usually lower in small populations (Menges 1991; Keller and Waller 2002; Kochankova and Mandak 2009). Menges (1991), for example, found a correlation between population size and germination rate in the recently fragmented prairie species Silene regia (Menges 1991). Populations with more than 150 individuals had consistent germination rates greater than 
85\%. Populations with fewer than 150 individuals had variable germination rates within and between populations, possibly due to recent fragmentation and/or inbreeding depression. Small endemic populations may have difficulty increasing population size or simply persisting due to decreased germination rates; so understanding their germination requirements could inform management and prevent extinction.

Understanding the genetic structure of a population can also inform management decisions to enhance genetic variability and survival (Ellstrand and Elam 1993; Alsos et al. 2002; Dolan et al. 2004). Population genetic studies can determine the degree to which populations are genetically distinct. This can have important implications for managing narrow species. For example, the introduction of seed without careful consideration of population genetic structure and fitness can result in harmful changes to populations (Millar and Libby 1989). Experimental introduction of plants from multiple seed stocks could increase the success of re-establishment via heterosis and increased genetic diversity (Barrett and Kohn 1991). However, such practices risk disrupting locally adapted gene combinations (Antonovics 1976; Simberloff, 1988; Barrett and Kohn 1991). Re-establishing populations from mixed seed sources will decrease population differentiation, but successfully re-established populations with long-term survival will likely differentiate again over time (Barrett and Kohn 1991). Godt et al. (1996) recommend introducing seeds from ecologically similar, but genetically diverse populations to maintain environmental adaptations and increase genetic diversity within the populations. Conservation plans that are approached experimentally increase our knowledge of population biology, and can inform specific goals of future conservation plans (Barrett and Kohn 1991). 
We studied, Phacelia cookei Constance \& Heckard (Boraginaceae, formerly Hydrophyllaceae, Olmstead et al. 2000), a rare annual limited to a three-mile radius near the northwest of the base of Mt. Shasta in Northern California. This species has a prostrate growth form, diminutive stature, and is found growing in small populations on bare soil. It completes its lifecycle in two to three months in the late spring through mid summer. The purpose of this study was to determine the habitat preferences, germination requirements, and population genetic structure in order to develop management strategies. 


\section{CHAPTER II}

\section{METHODS}

\section{Species Description}

Phacelia cookei is a small annual herb $(2-15 \mathrm{~cm})$ that occurs in areas of high disturbance in and along dirt roads where there is low surface organic matter and low competition from other plants (Horner-Till 1982). Flower are 1-1.5 mm wide and can produce seeds in the absence of pollinators (Patterson, personal observation) indicating that $P$. cookei is likely capable of self-fertilization. This species completes its life cycle between late May and early August. These sites occur on 0 to 35 percent slopes, and at elevations of 1330 to $1650 \mathrm{~m}$ in Shasta County, California. The community associations in which it has been found include the Chrysothamnus nauseosus Association, Pinus ponderosa Association and Arctostaphylos patula/Ceanothus velutinus Association (Sawyer and Keeler-Wolfe 1995; Barbour et al. 2007).

Populations of P. cookei appear to be isolated due to restricted seed dispersal and scarcity of appropriate habitats. Approximately half of seed dispersal is by gravity, and the other half occurs when the plants dry and detach from their roots, after which they tumble short distances in the wind (Horner-Till 1982). We identified four spatially distinct populations: Populations 1 (UTME 0566220, UTMN 4600778) and 4 (UTME 0567069, UTMN 4598387) were separated by approximately $2.4 \mathrm{~km}$, and populations 6 and7 (UTME 0562769, UTMN 4598057) were approximately 5.3 km from population 1. 
Population numbers are consistent with the numbers assigned in the habitat survey (see Table 1).

TABLE 1. Site locations and site categorization for a survey of Phacelia cookei habitat in Siskiyou County, California, USA, August 2009.

\begin{tabular}{lll}
\hline Site & $\begin{array}{c}\text { Location } \\
\text { (UTME, UTMN) }\end{array}$ & \multicolumn{1}{c}{ Site category } \\
\hline $01^{*}$ & 0566220,4600778 & Historical occurrence \\
02 & 0566895,4599400 & Historical occurrence \\
03 & 0566956,4599347 & Historical occurrence \\
$04^{*}$ & 0567069,4598387 & Historical occurrence \\
05 & 0567639,4597927 & Potential habitat \\
$06^{*}$ & 0562769,4598057 & Historical occurrence \\
$07^{*}$ & 0562978,4597937 & Historical occurrence \\
08 & 0563037,4597904 & Potential habitat \\
09 & 0561107,4599508 & Potential habitat \\
10 & 0560233,4599200 & Volcanic rock pit \\
11 & 0559970,4598891 & Volcanic rock pit \\
12 & 0562392,4597949 & Potential habitat \\
13 & 0562466,4597915 & Potential habitat \\
14 & 0562629,4598024 & Potential habitat \\
15 & 0562743,4589015 & Potential habitat
\end{tabular}

* indicates Phacelia cookei was present at the survey site.

\section{Habitat Survey}

The habitat was surveyed to determine associated vegetation, percent cover of bare ground, litter and vegetation, and to evaluate soil characteristics. Fifteen sites were surveyed on August 17 and 18, 2009, following the California Native Plant Society (CNPS) Vegetation Rapid Assessment survey protocol (CNPS Vegetation Committee 2007), for associated species, elevation, and habitat and vegetation descriptions. In 
addition to the rapid assessment surveys, percent cover of bare ground, litter and vegetation was measured within three to five $0.5 \mathrm{~m}^{2}$ quadrats haphazardly placed within the area considered to be potentially suitable habitat for $P$. cookei. For comparison, the quadrat was also haphazardly placed outside of the habitat area three times per site. A half-meter square quadrat was used because habitat areas were typically small or along narrow road margins. Vegetation cover was recorded as the percent cover of individual species within $0.5 \mathrm{~m}^{2}$. We compared habitat characteristics (percent bare ground, litter, and vegetation) among sites using a non-parametric Kruskal-Wallis test.

Surveyed sites were locations in which the plant was known to occur historically based on previous surveys conducted by Edwards and Schierenbeck, potential habitat, or sites near volcanic rock pits (Table 1). Potential habitat was determined haphazardly based on perceived similarity to historical sites. These locations were within the geographical range for $P$. cookei and had two or more of the following characteristics: a high level of disturbance as evidenced by tire tracks, low percent canopy cover, low amounts of competing vegetation and/or litter, and/or sand substrate. Volcanic rock pits were included as potential habitat because $P$. cookei is closely associated with dirt road margins that are maintained with a layer of volcanic rock. Seed could have been distributed in the volcanic road-bed material or it could be critical to habitat soil properties. The volcanic rock pits are located near the $P$. cookei sites and produce rocks very similar to that found in the roadbed.

A soil sample was collected from the approximate center of each survey site for analysis to determine whether soil texture and nutrient content limit colonization into new habitat. Soil was air-dried and passed through a $2 \mathrm{~mm}$ sieve to remove gravels. Cations 
were extracted using pH 7.0 ammonium acetate (Thomas 1984), with quantification of Ca, Mg, Na, and K by atomic adsorption/emission spectroscopy and data converted to meq/100g. Extractable cations are a robust measurement of potentially available forms (Thomas 1984). The soil cation exchange capacity (CEC) was gauged by the sum of extractable cations. Immiscible displacement (ID) was used as a proxy for cations and anions in the soil-solution (Mubarek and Olsen 1976) with cations $\mathrm{Ca}^{2+}, \mathrm{Mg}^{2+}, \mathrm{Na}^{+}$, and $\mathrm{K}^{+}$quantified by atomic adsorption/emission spectroscopy and anions $\mathrm{Cl}^{-}$and $\mathrm{SO}_{4}{ }^{-2}$, and ortho-P by ion chromatography. Cations and anions in the soil solution are readily available for plant root uptake. Given the $\mathrm{pH}$ of these soils (see results), we employed the Bray method to gage phosphorus availability (Bray and Kurtz 1945) with quantification by vanomolybdate chemistry, a colorimetric reagent, using flow injection to use small samples. The ratio of Bray extractable to ID phosphorus was calculated to more accurately measure the amount of phosphorus in the soil.

Nitrogen availability was quantified by KCl-extraction (Bundy and Meisinger 1994) with quantification of ammonium and nitrate using the Lachat autoanalyzer. The mole percent of ammonium in $\mathrm{KCl}$ extracts was determined as it often is related by plant succession and disturbance history (Blank, personal communication). Soil pH was measured twice: in a $0.01 \mathrm{CaCl}_{2}$ matrix and in a $\mathrm{NaF}$ matrix. The reaction of F- with poorly ordered hydrous oxides causes an increase in $\mathrm{pH}$ relative to that measure in aqueous matrix and can be a good proxy for levels of volcanic ash in the sample (Blank, personal communication). To assess soil texture coarse weight, fine weight, total weight, percent coarse fragments were measured. Percentage water at saturation was measured to determine the water holding capacity of the soil. Soil tests were conducted at USDA 
Agriculture Research Service in Reno, Nevada by Exotic and Invasive Weeds Research Soil Scientist Robert Blank.

We compared soil characteristics among sites classified as historical occurrences, potential habitat, and volcanic rock pits using a non-parametric Kruskal-Wallis test. The same test was used to compare soil characteristics between historical occurrence sites and historical occurrence sites with $P$. cookei present to determine if $P$. cookei is an edaphic endemic.

\section{Germination Methods}

We conducted two germination experiments to identify germination cues that would produce the highest germination rates, information that could then be used to estimate germination windows in the field and determine the feasibility of ex situ propagation. The purpose of the first germination experiment was to determine if acid scarification alone or in combination with five weeks of cold stratification, and two different temperature cycles would produce the highest percent germination. The purpose of the second germination experiment was to determine the combination of afterripening, cold stratification, and germination temperature treatments that produced the highest percent germination.

Collection and Seed Separation. Twenty-five dried plants were collected from each of the three populations 1, 4, and 6 and 7 on August 9, 2008. Seeds were separated from dried plant material and stored in labeled coin envelopes by parent plant at room temperature for three months.

Viability Testing. Four samples of fifty seeds from each population were tested for viability using the 1\% 2,3,5-triphenyl tetrazolium method (Lakon 1949). A 1\% 
tetrazolium solution was prepared, and seeds were pierced and soaked in the solution overnight in the dark. Seeds were considered viable if embryos stained dark pink. Mean viability for each population to adjust the percent germination in germination experiments 1 and 2, so that percent germination values reflect the proportion of viable seed that germinated.

Germination Experiment 1. The seeds from three different populations were subjected to 14 different treatment combinations in a factorial design including acid scarification (5, 10, or $15 \mathrm{~min}$ ), moist cold stratification (present or absent), and temperature during germination (cycling $5^{\circ} \mathrm{C}$ in the dark for $12 \mathrm{hr}$. followed by $25^{\circ} \mathrm{C}$ or $30^{\circ} \mathrm{C}$ in the light; Table 2). Acid scarification and moist cold stratification were conducted at California State University-Chico. One seed from each maternal plant collected in the field was included in each treatment combination (approximately 20 per population), and soaked in concentrated sulfuric acid for 5, 10, or 15 minutes then rinsed for two minutes in deionized water. Treated seeds were allowed to dry overnight. Seeds assigned to receive cold moist stratification were placed in beakers with moist perlite on October 31, 2008, and stored at $4^{\circ} \mathrm{C}$ for five weeks. Seeds that did not receive cold moist stratification were treated on December 12, 2008. One set of seeds did not receive acid scarification or cold stratification to serve as a control.

Following scarification or stratification treatments the seeds were placed on moist filter paper in $9 \mathrm{~cm}$ diameter Petri dishes and incubated for four weeks at one of two fluctuating temperature regimes following Horner-Till (1982). In one group, seeds were held for 12 hours each day at $5^{\circ} \mathrm{C}$ then temperature was increased to $25^{\circ} \mathrm{C}$ for the 
TABLE 2. Treatments applied to Phacelia cookei seeds in tests to break dormancy ("Germination Experiment 1" see Methods). Treatments included including sulfuric acid scarification, cold moist stratification, and temperature fluctuations, in which $24 \mathrm{hr}$ cycles consisted of $12 \mathrm{hr}$ at the low temperature and $12 \mathrm{hr}$ at the high temperature indicated.

\begin{tabular}{ccc}
\hline Acid Scarification & Cold Moist Stratification & Temperature \\
\hline 5 min. & 5 Weeks & $5^{\circ} \mathrm{C} / 25^{\circ} \mathrm{C}$ \\
$10 \mathrm{~min}$. & 5 Weeks & $5^{\circ} \mathrm{C} / 25^{\circ} \mathrm{C}$ \\
$15 \mathrm{~min}$. & 5 Weeks & $5^{\circ} \mathrm{C} / 25^{\circ} \mathrm{C}$ \\
$0 \mathrm{~min}$. & None & $5^{\circ} \mathrm{C} / 25^{\circ} \mathrm{C}$ \\
$5 \mathrm{~min}$. & None & $5^{\circ} \mathrm{C} / 25^{\circ} \mathrm{C}$ \\
$10 \mathrm{~min}$. & None & $5^{\circ} \mathrm{C} / 25^{\circ} \mathrm{C}$ \\
$15 \mathrm{~min}$. & None & $5^{\circ} \mathrm{C} / 25^{\circ} \mathrm{C}$ \\
$5 \mathrm{~min}$. & 5 Weeks & $5^{\circ} \mathrm{C} / 30^{\circ} \mathrm{C}$ \\
$10 \mathrm{~min}$. & 5 Weeks & $5^{\circ} \mathrm{C} / 30^{\circ} \mathrm{C}$ \\
$15 \mathrm{~min}$. & 5 Weeks & $5^{\circ} \mathrm{C} / 30^{\circ} \mathrm{C}$ \\
$0 \mathrm{~min}$. & None & $5^{\circ} \mathrm{C} / 30^{\circ} \mathrm{C}$ \\
$5 \mathrm{~min}$. & None & $5^{\circ} \mathrm{C} / 30^{\circ} \mathrm{C}$ \\
$10 \mathrm{~min}$. & None & $5^{\circ} \mathrm{C} / 30^{\circ} \mathrm{C}$ \\
$15 \mathrm{~min}$. & None & $5^{\circ} \mathrm{C} / 30^{\circ} \mathrm{C}$ \\
\hline
\end{tabular}

reminder of each 24-hour period. The second group was held 12 hours each day at $5^{\circ} \mathrm{C}$ then the temperature was increased to $30^{\circ} \mathrm{C}$ for the remainder of the 24-hour period.

We compared percentage germination among populations and treatments using Kruskal-Wallis tests.

Germination Experiment 2. A second germination experiment was used to test the effects of two after-ripening treatments in conjunction with cold moist stratification on germination. Twelve different treatment combinations were applied to the seeds (Table 3). Treatments were chosen using the Horner-Till thesis (1982) and the germination decision tree (Meyer 2006). Seeds were placed on 12 separate $50 \mathrm{~mm}$ Petri dishes per 
TABLE 3. Treatments applied to Phacelia cookei seeds in tests to break dormancy. Treatments included after-ripening, cold stratification, and temperature fluctuations, in which each $24 \mathrm{hr}$. cycle consisted of $12 \mathrm{hr}$ at the low temperature alternating with $12 \mathrm{hr}$ at the high temperature indicated.

\begin{tabular}{|c|c|c|c|}
\hline \multicolumn{2}{|c|}{$\begin{array}{l}\text { After-ripening } \\
\text { (2 Weeks) }\end{array}$} & \multirow[t]{2}{*}{ Cold Stratification at $2^{\circ} \mathrm{C}$} & \multirow[t]{2}{*}{ Temperature } \\
\hline Temp. & Moisture & & \\
\hline $\begin{array}{l}--- \\
--\end{array}$ & $\begin{array}{l}--- \\
--\end{array}$ & 8 Weeks & $2^{\circ} \mathrm{C} / 10^{\circ} \mathrm{C}$ \\
\hline ---- & ---- & 8 Weeks & $5^{\circ} \mathrm{C} / 25^{\circ} \mathrm{C}$ \\
\hline ---- & ---- & 12 Weeks & $2^{\circ} \mathrm{C} / 10^{\circ} \mathrm{C}$ \\
\hline ---- & ---- & 12 Weeks & $5^{\circ} \mathrm{C} / 25^{\circ} \mathrm{C}$ \\
\hline $15^{\circ} \mathrm{C}$ & Wet & 8 Weeks & $2^{\circ} \mathrm{C} / 10^{\circ} \mathrm{C}$ \\
\hline $15^{\circ} \mathrm{C}$ & Wet & 8 Weeks & $5^{\circ} \mathrm{C} / 25^{\circ} \mathrm{C}$ \\
\hline $15^{\circ} \mathrm{C}$ & Wet & 12 Weeks & $2^{\circ} \mathrm{C} / 10^{\circ} \mathrm{C}$ \\
\hline $15^{\circ} \mathrm{C}$ & Wet & 12 Weeks & $5^{\circ} \mathrm{C} / 25^{\circ} \mathrm{C}$ \\
\hline $40^{\circ} \mathrm{C}$ & Dry & 8 Weeks & $2^{\circ} \mathrm{C} / 10^{\circ} \mathrm{C}$ \\
\hline $40^{\circ} \mathrm{C}$ & Dry & 8 Weeks & $5^{\circ} \mathrm{C} / 25^{\circ} \mathrm{C}$ \\
\hline $40^{\circ} \mathrm{C}$ & Dry & 12 Weeks & $2^{\circ} \mathrm{C} / 10^{\circ} \mathrm{C}$ \\
\hline $40^{\circ} \mathrm{C}$ & Dry & 12 Weeks & $5^{\circ} \mathrm{C} / 25^{\circ} \mathrm{C}$ \\
\hline
\end{tabular}

individual plant. Population 1 had 16 individuals, population 4 had 14 individuals, and Populations 6 and 7 had 25 individuals each included in this experiment for a total of 660 plates. The number of seeds in each dish varied between 1-10 seeds depending on the number available per plant. All seeds from a single plant assigned to receive the $40^{\circ} \mathrm{C}$ treatment were combined into a single sealed vial to prevent loss of seed moisture, after which they were separated into Petri plates for cold stratification.

The criteria for germination was the protrusion of the radicle, which was visible to the naked eye. The percentage germination was compared among populations using a Kruskal-Wallis test. 
Isozyme Methods

A survey of allozyme variation was conducted to characterize population genetic variation within and between populations. Genetic variation can indicate the health of an individual population or a species because more genetically diverse populations have more evolutionary potential.

Sample Collection and Extraction. Fifty living plant samples were collected from each of populations 1 and 4, and 24 samples were collected from populations 6 and 7 (sites $6 \& 7$ were combined into one population due to low the number of individuals in each population and physical proximity) on June 8, 2009, stored in a plastic bag on ice or refrigerated up to 48 hours until extraction. All tissue samples were crushed in a chilled ceramic spot plate using a glass pestle with an extraction buffer modified from Broyles and Wyatt (1990). The extract was filtered through Miracloth, adsorbed onto 3 x $10 \mathrm{~mm}$ wicks cut from Whatmann 3MM chromatography paper, and stored at $-70^{\circ} \mathrm{C}$ until electrophoresis was performed. Wicks were loaded onto $12.5 \%$ hydrolyzed potato starch gels and subjected to horizontal electrophoresis following Soltis and Soltis (1989).

Gel systems. The following isozymes and buffer combinations were used to determine genetic variability within and between populations. A tris-citrate buffer(pH8.0) (Meizel and Market 1967) was used to resolve isocitrate dehydrogenase (IDH:EC:1.1.1.41), 6phosphoguconate (PGD:EC:1.1.1.44), glyceraldehyde-6-phosphate dehydrogenase (G6PDH:EC:1.1.1.49), glutamate dehydrogenase (GDH:EC:1.4.1.2), and glyceraldehyde-3-phosphate dehydrogenase (G-3PDH:EC:1.2.1.9). A histidine-citrate buffer (pH 7.0) (Fildes and Harris 1966) was used to resolve phosphoglucomutase (PGM:EC:5.4.2.2), menadione reductase (MNR:EC:1.6.99), malic enzyme 
(ME:EC:1.1.1.40), phosphglucoisomerase (PGI:EC:5.3.1.9), and triose-phosphate isomerase (TPI:EC:5.3.1.1). A tris-borate-EDTA buffer (pH 8.6) (Markert and Faulhaber 1965) was used to resolve diaphorase (DIA:EC:1.6.2.2), UTP-glucose 1-phosphate uridylyltranferase (UGPP:EC:2.7.7.9), aldolase (ALD:EC:4.1.2.13), glutimate oxaloacetate transaminase (GOT:EC:2.6.1.1), and shikimate dehydrogenase (SHK:EC:1.1.1.25). All enzyme assays followed Wendel and Weeden (1989) except UGPP, which followed Manchenko (1994). Stains were incubated at $37^{\circ} \mathrm{C}$ in the dark until bands appeared.

Analysis. We used POPGENE (Yeh et al. 1999) to calculate allele frequencies, FStatistics, geneflow, heterozygosity, and the effective number of alleles. F-statistics were calculated following Weir (1990) to determine deviations from Hardy-Weinberg equilibrium. Total gene diversity $\left(\mathrm{H}_{t}\right)$ and mean diversity within populations $\left(\mathrm{H}_{\mathrm{s}}\right)$ were calculated following Nei (1973, 1978). The effective number of alleles was calculated following Hartl and Clark (1989). 


\section{CHAPTER III}

\section{RESULTS}

\section{Habitat Surveys}

Percentage bare ground cover did not differ among types of habitat [mean (SD) historical occurrence $=74.59$ (34.33), potential habitat $=77.86$ (31.79), and volcanic rock pits $=85.83$ (22.45); $H=2.89, P=0.2]$. Percentage cover by litter also did not differ among sites [mean(SD) historical occurrence $=20.18(34.24)$, potential habitat $=17.38$ (23.58), and volcanic rock pits $=2.50(4.18) ; H=3.71, P=0.2]$. Percentage vegetation cover, however, was significantly higher in the historical occurrence and volcanic rock pit sites than in the potential habitat [mean (SD) historical occurrence $=14.64$ (28.37), volcanic rock pits $=11.67(19.15)$, potential habitat $=4.05(11.53) ; H=8.28, P=0.016]$.

Nama densa A. Gray was the most closely associated species with $P$. cookei, because it was found at all four of the sites that had P. cookei present (Table 4). Sites classified as potential habit, historical occurrence (without $P$. cookei), and volcanic rock pit did not have Nama densum present.

Other species commonly associated with P. cookei were Bromus tectorum L., Gayophytum sp., Erigeron fillifolius Nutt., and Gutierrezia microphala (DC.) A. Gray, which were found at three of the four sites that had P. cookei present. Achnatherum occidentale (Thurber) Barkworth , Agrostis idahoensis Nash, Artemisia tridentate Nutt., Chenopodium atroviens Rydb., Chenopodium botry L., Chysothamnus nauseosus (Pallas) 
TABLE 4. Percentage cover of plants present at sites surveyed in a study characterizing habitat of Phacelia cookei. Site numbers correspond to locations in Table 1. Missing values indicate that the species was not present at that location. Surveys were conducted in Siskiyou County, CA, USA in August 2009.

\begin{tabular}{|c|c|c|c|c|c|c|c|c|c|c|c|c|c|c|c|}
\hline \multirow[b]{2}{*}{ Species } & \multicolumn{15}{|c|}{ Site Number } \\
\hline & 1 & 4 & 6 & 7 & 2 & 3 & 5 & 8 & 9 & 12 & 13 & 14 & 15 & 10 & 11 \\
\hline Phacelia cookei & 2 & 1 & $<1$ & $<1$ & & & & & & & & & & & \\
\hline Nama densum & 1 & 1 & 5 & 1 & & & & & & & & & & & \\
\hline Gutierrezia microcephala & 1 & 1 & 5 & & & & 1 & & & & & & & & \\
\hline Bromus tectrum & 1 & 1 & 1 & & 1 & & 1 & & & 3 & 30 & 1 & 1 & & \\
\hline Erigeron filifolius & 1 & 1 & 1 & & 1 & & 1 & 1 & & & & & & & \\
\hline Gayophytum sp. & 1 & 1 & & 1 & & 1 & 1 & & & & & & & 1 & \\
\hline Chysothamnus nauseosus & 5 & 5 & & & 1 & & & & & & 3 & & 1 & 1 & \\
\hline Chenopodium atroviens & 1 & & 1 & & & & & 1 & & & & & & & \\
\hline Mentzelia albicaulis & & 1 & 1 & & & & & & & & & & & & \\
\hline Purshia tridentata & 15 & & & & 5 & 5 & & 5 & & & & & & & \\
\hline Artemisia tridentata & 5 & & & & 5 & & & 5 & 3 & 20 & 5 & & 1 & & 1 \\
\hline Agrastis idahoensis & 1 & & & & 1 & 1 & & & & 2 & & & 1 & & 1 \\
\hline Achnatherum occidentalisis & 1 & & & & 1 & 1 & & & & & & & & & \\
\hline Pinus jeffreyi & 1 & & & & & 75 & & & & & & & & & \\
\hline Elymus elymoides & 1 & & & & 1 & 1 & 1 & & & & & & & & \\
\hline Epilobium sp. & 1 & & & & 1 & & 1 & & & & & & & & \\
\hline Leptodactylon pungens & 1 & & & & 1 & & & & 2 & & & & & & \\
\hline Chenopodium botry & & 5 & & & & & & & & & & & & & \\
\hline Phacelia hasta & & 5 & & & & & 1 & & & & & & & & \\
\hline Penstomon laetus var. sagittatus & & 1 & & & & & & & & & & & & & \\
\hline
\end{tabular}


Table 4 (Continued)

\begin{tabular}{|c|c|c|c|c|c|c|c|c|c|c|c|c|c|c|c|}
\hline \multirow[b]{2}{*}{ Species } & \multicolumn{15}{|c|}{ Site Number } \\
\hline & 1 & 4 & 6 & 7 & 2 & 3 & 5 & 8 & 9 & 12 & 13 & 14 & 15 & 10 & 11 \\
\hline Chamaesyce glyptosperma & & 1 & & & & & & & & & & & & & \\
\hline Stephanomeria sp. & & 1 & & & & & & & & & & & & & \\
\hline Erigonium nudum & & 1 & & & & & & & & & & & & & \\
\hline Sisymbrium altissimam & & & 1 & & & & & & & & & & & & \\
\hline Eriogonum baileyi & & & 1 & & & & & & & & & & & & \\
\hline Erigonium umbellatum & & & & 1 & & & & & & & & & & & \\
\hline Collomia grandiflora & & & & & 1 & 1 & & & & & & & & & \\
\hline Gilia sinuate & & & & & 1 & & & & & & 1 & & & & \\
\hline Pterospora andromedea & & & & & & 1 & & & & & & & & & \\
\hline Ribes cereum & & & & & & 5 & & & & & & & & & \\
\hline Ceanothus velatinus & & & & & & & 1 & & & & & & & & \\
\hline Arctostaphylos navadensis & & & & & & & 1 & & & & & & & & \\
\hline Delphenium sp. & & & & & & & 1 & & & & & & & & \\
\hline Nicotiana attenuata & & & & & & & 1 & & & & & & & & \\
\hline Chaenaetis douglasii & & & & & & & 1 & & & & & & & & \\
\hline Achillea milifolium & & & & & & & & & 1 & & & & & & \\
\hline Castilleja sp. & & & & & & & & & & & 1 & & & & \\
\hline Bromus carinatus & & & & & & & & & & & & 1 & & & \\
\hline Cryptantha sp. & & & & & & & & & & & & & 1 & & \\
\hline Verbascum thapsus & & & & & & & & & & & & & & 1 & \\
\hline Juniperus sp. & & & & & & & & & & & & & & & 1 \\
\hline Eriophyllum lanatum var. ovovatum & & & & & & & & & & & & & & & 1 \\
\hline Total \% veg. cover & 40 & 26 & 17 & 4 & 20 & 91 & 12 & 12 & 6 & 25 & 40 & 2 & 5 & 3 & 4 \\
\hline
\end{tabular}


Britton, Elymus elymoides (Raf.) Swezey, Epilobium sp., Leptodactylon pungens (Torry) Rybd., Penstemon laetus var. sagittatus (Keck) McMinn, Phacelia hasta ssp. cf. compacta (Brand) Heckard, Pinus jeffreyi Grev. \& Balf., Purshia tridentate (Pursh) DC., and Sisymbrium altissimam L. were present at half of the sites that had P. cookei present.

Bromus tectorum, an invasive annual grass that excludes native plants and increases the threat of wild fires (Klemmedson and Smith 1964), was documented at nine of the 14 sites. Most sites had very low percent cover (1\%) of Bromus tectorum, except site 13 where it reached $30 \%$.

Elevation for all sites at which $P$. cookei was found ranged from 1,107 $\mathrm{m}$ to 1,408 $\mathrm{m}$. Disturbance, evident from tire tracks and crushed vegetation, was observed at all sites that had $P$. cookei present except site 4 , which was near railroad tracks.

Delany and Oosen-Avis soil families are found in and round the study sites (USDA/NRCS 2010). They are characterized by a sandy texture and igneous parent material (USDA/NRCS 2010). The mean coarse weight at the volcanic rock pits was much higher than the course weight of potential habitat and historic habitat (Table 5), because the volcanic rock pits are sources of a rocky roadbed material whereas the historic and potential habitat areas are relatively sandier. In addition, mean $\mathrm{pH}$ was lower at volcanic rock pit sites than at potential habitat and historical occurrence sites (Table 5). Nonetheless, no significant differences were detected among sites surveyed for any of the soil characteristics we measured (Table 5). Historical sites with and without $P$. cookei did not differ significantly, so they were grouped for analysis. The lack of distinction among sites indicates that soil is not limiting the distribution of $P$. cookei, at least within its known geographical range 
TABLE 5. Mean (SD) responses from soil analyses conducted during a survey of habitat of Phacelia cookei. Sites were categorized as historical occurrence $(n=6)$, potential habitat $(n=7)$, or volcanic rock pit sites $(n=2$; see Table 1$)$. Soil samples were collected during August 2009 in Siskiyou County, California. See Methods for explanation of soil analysis. Test Statistic was calculated using the non-parametric Kruskall Wallace test to determine significant differences in ranked means.

\begin{tabular}{|c|c|c|c|c|}
\hline Soil Analysis & $\begin{array}{l}\text { Historical } \\
\text { occurrence } \\
\text { Mean(SD) } \\
\end{array}$ & $\begin{array}{c}\text { Potential } \\
\text { habitat } \\
\text { Mean(SD) }\end{array}$ & $\begin{array}{c}\text { Volcanic Rock } \\
\text { Pits } \\
\text { Mean (SD) } \\
\end{array}$ & $\begin{array}{l}\text { Test } \\
\text { Stat } \\
(\mathrm{H}) \\
\end{array}$ \\
\hline meq/100g acetate $\mathrm{Ca}$ & $2.15(2.22)$ & $1.09(0.60)$ & $3.40(3.71)$ & 0.59 \\
\hline meq/100 g acetate $\mathrm{Mg}$ & $0.57(0.72)$ & $0.16(0.08)$ & $0.98(0.91)$ & 3.21 \\
\hline meq/100g acetate $\mathrm{K}$ & $0.29(0.23)$ & $0.09(0.05)$ & $0.34(0.34)$ & 3.37 \\
\hline meq/100 g acetate $\mathrm{Na}$ & $4.51(0.75)$ & $4.62(0.21)$ & $4.65(0.59)$ & 0.0 \\
\hline $\begin{array}{l}\text { CEC by sum of cations } \\
\text { (meq/100g) }\end{array}$ & $7.53(2.48)$ & $5.96(0.64)$ & $9.36(4.36)$ & 4.34 \\
\hline ug/g Bray P as P & $79.48(57.4)$ & $93.69(34.03)$ & 17.47 (18.99) & 4.03 \\
\hline $\mathrm{ug} / \mathrm{mL}$ ID Ca & 3.13 (1.64) & $7.54(7.48)$ & $3.75(3.75)$ & 1.14 \\
\hline $\mathrm{ug} / \mathrm{mL}$ ID Mg & $1.63(1.65)$ & $2.14(1.62)$ & $2.65(2.33)$ & 0.71 \\
\hline $\mathrm{ug} / \mathrm{mL}$ ID K & $6.90(5.40)$ & $5.03(2.62)$ & $5.85(6.72)$ & 0.35 \\
\hline $\mathrm{ug} / \mathrm{mL}$ ID Na & $2.42(1.87)$ & $2.27(1.22)$ & $2.60(0.42)$ & 0.7 \\
\hline coarse wt. & $22.24(26.28)$ & 34.37 (27.92) & 221.76(164.07) & $5.67 \dagger$ \\
\hline fine wt. & 285.38(106.46) & 393.66(88.28) & $310.8(64.45)$ & 3.84 \\
\hline total wt. & $307.62(123.90)$ & $428.03(75.15)$ & $532.52(228.52)$ & 3.75 \\
\hline$\%$ coarse frag & $6.47(6.00)$ & $8.52(7.45)$ & $38.58(14.26)$ & $5.16 \dagger$ \\
\hline $\begin{array}{l}\text { ppm KCl NH4 } \\
\text { ug/g KCL }\end{array}$ & $0.61(0.23)$ & $1.10(1.19)$ & $1.07(1.00)$ & 0.68 \\
\hline$(\mathrm{mmmol} / \mathrm{kg})$ & $1.81(0.68)$ & $3.25(3.56)$ & $3.19(3.00)$ & 0.49 \\
\hline $\mathrm{KCl}$ NH4 (mmol/kg) & $0.10(0.04)$ & $0.18(0.2)$ & $0.18(0.17)$ & 0.49 \\
\hline ppm KCl NO3 & $2.24(1.93)$ & $4.33(3.63)$ & $3.7(3.86)$ & 1.54 \\
\hline ug/g KCl NO3 & $6.58(5.66)$ & $12.70(10.63)$ & $11.08(11.61)$ & 0.54 \\
\hline KCl NO3 (mmol/kg) & $0.11(0.09)$ & $0.20(0.17)$ & $0.18(0.19)$ & 1.53 \\
\hline total $\mathrm{KCl} \mathrm{N}(\mathrm{mmol} / \mathrm{kg})$ & $0.21(0.12)$ & $0.39(0.3)$ & $0.36(0.35)$ & 0.99 \\
\hline Mole $\% \mathrm{KCl}$ as $\mathrm{NH} 4$ & $57.75(24.64)$ & $50.36(27.04)$ & $52.39(5.26)$ & 1.54 \\
\hline ug/ml ID Cl & $1.97(1.12)$ & $1.28(0.79)$ & $1.49(1.07)$ & 1.87 \\
\hline $\mathrm{ug} / \mathrm{mL}$ ID SO4 & $2.34(1.39)$ & $2.53(2.32)$ & $4.25(3.90)$ & 0.75 \\
\hline $\mathrm{ug} / \mathrm{ml}$ ID $\mathrm{P}$ as $\mathrm{P}$ & $0.29(0.4)$ & $0.46(0.41)$ & $0.26(0.18)$ & 2.06 \\
\hline $\mathrm{CaCl} \mathrm{pH}$ & $5.79(0.2)$ & $5.50(0.45)$ & $6.26(0.43)$ & 4.23 \\
\hline $\mathrm{NaF} p \mathrm{H}$ & $9.07(0.47)$ & $8.52(0.62)$ & $8.51(0.41)$ & 3.56 \\
\hline pH Diff & $3.28(0.5)$ & $3.02(0.32)$ & $2.26(0.02)$ & $5.63 \dagger$ \\
\hline$\%$ water at saturation & 28.85 (6.97) & $25.84(2.7)$ & $26.41(6.25)$ & 0.22 \\
\hline ug/g ID $\mathrm{P}$ as $\mathrm{P}$ & $\begin{array}{r}0.10(0.15) \\
2085.07\end{array}$ & $\begin{array}{r}0.12(0.11) \\
2267.67\end{array}$ & $0.07(0.06)$ & 0.91 \\
\hline ratio bray to ID $\mathrm{P}$ & (1518.57) & (3725.59) & $199.06(81.95)$ & 3.73 \\
\hline
\end{tabular}

$\dagger 0.1>P>0.6$. 


\section{Germination Results}

Viability Testing. A high percentage of seeds stained positive for enzyme activity following the tetrazolium test (positive test observed in $89 \%$, 90\%, and $93 \%$ of seeds respectively, from populations 1,4, and 6/7), suggesting relatively high levels of seed viability.

Germination Experiment 1. We found no significant differences in percentage germination among any of the population by treatment combinations $(H=0.07, P=0.9)$, so we combined data across populations for subsequent analyses to increase out power to detect treatment effects. Nonetheless we found no difference in percent germination between the two germination temperature cycles $\left(5 / 25^{\circ} \mathrm{C}\right.$ vs. $\left.5 / 30^{\circ} \mathrm{C}\right)(H=0.20, P=0.66$; Table 6) or among scarification times in acid $(H=2.39, P=0.50$; Table 6) (we note, however, that 15 min treatment was destroying the seeds). We also found that difference in percentage germination between the acid-only versus the acid-and-cold-stratification treatments statistically insignificant $(H=0.15, P=0.70$; Table 6$)$. When we compared all ten treatment combinations there was no significant difference among treatments $(H=$ $11.40, P=0.6)$.

Germination Experiment 2. We found no significant differences in percentage germination among any of the population by treatment combinations $(H=0.17$ to 2.51 , $P=0.3$ to 0.9 ; Table 7 ), so we combined data across populations for subsequent analyses to increase our power to detect treatment effects.

Percentage germination was not affected by after-ripening treatment $(H=1.42, P=$ 0.50 ; Table 7) or length of cold stratification $(H=0.03, P=0.87$; Table 7). Percent 
TABLE 6. Mean (SD) percentage germination of Phacelia cookei seeds in a test of dormancy cues (“Germination Experiment 1" see Methods). Treatments included acid scarification, cold stratification, and germination temperature.

\begin{tabular}{lcc}
\hline Treatment & Percentage Germination & Test Statistic $(\mathrm{H})$ \\
\hline Acid Scarification Time & $2.07(2.31)$ & 2.39 \\
$0 \mathrm{~min}$ & $6.05(12.02)$ & \\
$5 \mathrm{~min}$ & $1.09(2.03)$ & \\
$10 \mathrm{~min}$ & $0.88(3.03)$ & \\
$15 \mathrm{~min}$ & & \\
Cold Stratification & $3.2(8.47)$ & \\
None & $1.8(4.21)$ & \\
5 weeks & & \\
Germination Temperature & $3.34(9.06)$ & \\
$5 / 25^{\circ} \mathrm{C}$ & $1.83(3.91)$ & \\
$5 / 30^{\circ} \mathrm{C}$ &
\end{tabular}

TABLE 7. Mean (SD) percentage germination of Phacelia cookei seeds in a test of dormancy cues (“Germination Experiment 2" see Methods). Treatments included afterripening, cold stratification, and germination temperature cycle.

\begin{tabular}{lcc}
\hline Treatment & Avg. percentage germination & Test Statistic $(\mathrm{H})$ \\
\hline Afterripening & $3.40(4.09)$ & 1.42 \\
$\quad$ None & $14.40(14.83)$ & \\
Warm/Moist $\left(15^{\circ} \mathrm{C}\right)$ & $3.28(4.97)$ & \\
Hot $/$ Dry $\left(40^{\circ} \mathrm{C}\right)$ & & 0.03 \\
Cold Stratification $\left(2^{\circ} \mathrm{C}\right)$ & $8.40(12.25)$ & \\
8 Weeks & $5.68(8.24)$ & $7.41^{*}$ \\
12 weeks & $13.35(11.10)$ & \\
Germination Temp. & $0.70(1.71)$ & \\
$5 / 25^{\circ} \mathrm{C}$ & & \\
$2 / 10^{\circ} \mathrm{C}$ & & \\
$* p<0.05$ & &
\end{tabular}

germination was higher among seeds that were exposed to a $5 / 25^{\circ} \mathrm{C}$ temperature cycle than those in the $2 / 10^{\circ} \mathrm{C}$ temperature cycle $(H=7.41, P=0.01$; Table 7$)$. 
We observed no germination under the following conditions: (1) 8 weeks cold stratification /germinated at 2/10, (2) 12 weeks of cold stratification/ germinated at 2/10 ${ }^{\circ} \mathrm{C}$, (3) warm after-ripening/8 weeks cold stratification/germinated at $2 / 10^{\circ} \mathrm{C}$, (4) hot after-ripening/ 8 weeks cold stratification/ germinated at $2 / 10^{\circ} \mathrm{C}$, and (5) hot afterripening/12 weeks cold stratification/ germinated at $2 / 10^{\circ} \mathrm{C}$.

\section{Allozyme Variation}

Seventeen of the 19 putative allozyme loci we resolved were monomorphic (Table 8). Only DIA and MNR were polymorphic. Both DIA and MNR stain for a varied group of

TABLE 8. Allele frequencies at two variable isozyme loci in three populations of Phacelia cookei. Sample size per locus: Pop 1 (50); Pop 4 (50); Pop 6/7 (24). Mean expected heterozygosity $\left(\mathrm{H}_{\mathrm{s}}\right)$ and mean number of alleles per locus per polymorphic loci (AP) are shown for each population.

\begin{tabular}{lllll}
\hline & & \multicolumn{3}{c}{ Populations } \\
\cline { 3 - 5 } Locus & Allele & 1 & 4 & $6 / 7$ \\
\hline DIA & a & 0.18 & 0.39 & 0.44 \\
& b & 0.82 & 0.61 & 0.56 \\
\hline MNR & a & 0.08 & 0.25 & 0.23 \\
& b & 0.20 & 0.24 & 0.27 \\
& c & 0.72 & 0.51 & 0.5 \\
\hline $\mathrm{H}_{\mathrm{s}}$ & & $0.04(0.12)$ & $0.06(0.18)$ & $0.06(0.18)$ \\
\hline $\mathrm{AP}$ & & 2.5 & 2.5 & 2.5 \\
\hline
\end{tabular}

flavoproteins with little specificity (Solstis and Solstis 1989). In some plants these two markers stain for the same allozyme, or there may be overlap between the stains (Soltis and Soltis 1989), but we found banding patterns of these allozymes to be dissimilar for $P$. cookei, and thus we treated them as distinct loci. All populations had $10.53 \%$ 
polymorphic loci. The mean number of alleles at each population was 1.16 . The effective number of alleles for populations 1,4 , and 6/7 was $1.06,1.13$, and 1.14 respectively. The effective number of alleles did not deviate significantly from the mean number of alleles. Chi-squared goodness of fit tests indicated that allele frequencies (DIA $\chi^{2}=1.99, \mathrm{df}=1$, and $P=0.2)\left(\mathrm{MNR} \chi^{2}=7.24, \mathrm{df}=3\right.$, and $\left.P=0.06\right)$ did not significantly deviate from Hardy-Weinberg equilibrium.

Individual-locus estimates of inbreeding $\left(\mathrm{F}_{\mathrm{IS}}\right)$ were negative for MNR, and the mean for all populations (Table 9). DIA consistently had positive $F_{\text {IS }}$ values for population 1 and 4 and a negative value for population 6/7. MNR had negative $F_{I S}$ values ranging from -0.3352 to -0.1939 , and DIA had FIs values that overlapped zero ranging from -0.1005 to 0.1870. All three populations had negative mean $F_{\text {IS }}$ of -0.1344 . Jackknife estimates of heterozygote deficiency among populations $\left(\mathrm{F}_{\mathrm{ST}}\right)$ for MNR and DIA was 0.0292, and 0.0561 respectively, and the mean $\mathrm{F}_{\mathrm{ST}}$ value was 0.0409 . 
TABLE 9. Genetic diversity for two polymorphic allozyme loci in three Phacelia cookei populations. Jackknife estimates of heterozygote deficit within individuals $\left(\mathrm{F}_{\mathrm{is}}\right)$, observed total $\left(\mathrm{H}_{\mathrm{t}}\right)$ and populationlevel $\left(\mathrm{H}_{\mathrm{s}}\right)$ heterozygosities were calculated according to Nei (1973) using GenePop.

\begin{tabular}{llll}
\hline Locus & $\mathrm{F}_{\text {is }}$ & $\mathrm{H}_{\mathrm{T}}$ & $\mathrm{H}_{\mathrm{s}}$ \\
\hline Population 1 & & & \\
$\quad$ MNR & -0.265 & 0.560 & 0.435 \\
DIA & 0.007 & 0.240 & 0.295 \\
Pop. Means & -0.095 & $0.042(0.14)$ & $0.038(0.12)$ \\
Population 4 & & & \\
MNR & -0.194 & 0.740 & 0.620 \\
DIA & 0.117 & 0.420 & 0.476 \\
Pop. Means & -0.059 & $0.061(0.19)$ & $0.058(0.17)$ \\
Population 6/7 & & & \\
MNR & -0.335 & 0.833 & 0.624 \\
DIA & -0.101 & 0.542 & 0.492 \\
Pop. Means & 0.187 & $0.072(0.22)$ & $0.057(0.18)$ \\
All Populations & & & \\
MNR & -0.271 & 0.686 & 0.564 \\
DIA & 0.049 & 0.371 & 0.431 \\
Means & -0.134 & $0.056(0.18)$ & $0.052(0.16)$ \\
\hline
\end{tabular}




\title{
CHAPTER IV
}

\section{DISCUSSION}

\begin{abstract}
Habitat
We identified a number of areas near existing populations that appear to be suitable (low vegetation and litter cover, and high bare ground), but uncolonized habitat. We have identified treatment combinations that can break seed dormancy, albeit at low frequencies. Thus, managers could consider attempting to expand existing populations into some of these new areas by sowing seeds in to areas with low vegetation and litter cover. Genetic variation appears to be quite limited in $P$. cookei, which may ultimately limit this species prospects for recovery.
\end{abstract}

Associated species and percent cover of bare ground, litter, and vegetation maybe useful for locating potential habitat and new populations. Bourg et al. (2005), for example, successfully used classification and regression tree (CART) modeling and geographic information systems (GIS) computer software with habitat characteristics, such as forest type and elevation, to locate eight new occupied habitat patches of the rare forest plant turkeybeard (Xerophyllum asphodeloides). Associated species should be protected to maintain a strong native plant community and to reduce the chance of invasion by non-native plants, however openings in native plant communities should be maintained for potential habitat. 
Soil samples from all of the sites did not differ significantly with regard to nutrients and texture, which suggests that soil characteristics are not limiting the spread of $P$. cookei within its geographical range. The volcanic rock roadbed material, moreover, was not significantly different than the sand substrate, so a sandy substrate may not be a habitat requirement. The current limited distribution of $P$. cookei may instead reflect the limitations of its gravity and tumbleweed seed dispersal mechanisms (Horner-Till 1982), and the limited distribution of the Delaney and Oosen-Avis soil families (USDA/NRCS 2010). Another habitat characteristic that could limit the expansion of P. cookei populations is insufficient bare soil or too little disturbance in areas adjacent to extant populations. We observed that three of the four extant populations had signs of disturbance. All of the sites that had $P$. cookei present had high amounts of bare ground and low percent cover of vegetation and litter.

\section{Germination}

The Horner-Till (1982) thesis reported that radicles emerged from 60-75\% of $P$. cookei seeds when seeds were soaked in water, the ends of the seeds nicked, and the seeds were incubated for two weeks in a cycle of $1^{\circ} \mathrm{C}$ for 12 hours followed by $10^{\circ} \mathrm{C}$ for 12 hours. Using 1\% 2,3,5-triphenyl tetrazolium, a test for enzyme activity, we observed viability as high as $93 \%$.

Seed dormancy in P. cookei was not strongly affected by our physical (scarification) our physiological (stratification and afterripening) treatments, suggesting it may have multiple dormancy cues which have yet to be tested or non-cue responsive dormancy or (Meyer 2006). Non-cue responsive dormancy is a condition in which seeds are 
programmed to persist in the seed bank by not responding to physical and physiological dormancy breaking cues (Meyer 2006). Seeds exhibiting non-cue responsive dormancy can be a challenging to propagate from seed, so in situ conservation measures are more likely to be successful. We found, on the other hand, that the $5 / 25^{\circ} \mathrm{C}$ temperature cycle produced significantly higher germination rates than the $2 / 10^{\circ} \mathrm{C}$ temperature cycle. These temperatures are similar to the field temperatures reported by Horner-Till (1982), and may provide guidance for expanding the range into uncolonized, but apparently suitable habitat.

\section{Allozyme Variation}

Overall, isozyme variation was very low, which suggests $P$. cookei harbors limited population genetic diversity. This is consistent with the predictions of Hamrick and Godt (1989), who indicate that endemic, short- lived, selfing dicots with gravity dispersed seed are expected to have low amounts of genetic diversity. Phacelia cookei, which has all of these traits, has very low amounts of genetic diversity.

The populations are very similar genetically (low $F_{\mathrm{ST}}$ ), so there appears to be little concern for disrupting locally adapted genotypes if land managers dispersed seeds among populations or used them to colonize new sites. Population sizes could be expected to vary substantially from year to year, so if seeds are collected for this purpose, the number of seeds harvested from each population should be proportionate to the population size.

Our estimates of population genetic variation may have been low in part because samples of $P$. cookei tissue were collected only during one field season. Plants with small populations can maintain genetic diversity through a genetically diverse seed bank, so 
plants growing during one season may not be representative of the total genetic diversity of populations, including both living plants and dormant seeds (Del Castillo 1994; Harrison et al., in press). However, our sample sizes from populations 1 and 4 (50 individuals each) were adequate to sample at least some rare alleles across the 19 loci resolved, and the populations in that year contained several hundred individuals. Seventeen of those loci appeared to be fixed. Therefore, it is unlikely that sampling across multiple years (Ellstrand and Elam 1993; Cabin et al. 1998; McCue and Holtsford 1998) would result in much additional population variation. Nonetheless, since sampling across years may increase the probability of mining rare alleles, new populations established in suitable habitat should be seeded across multiple years to maximize the evolutionary potential of each population established.

Hamrick (1983) surveyed the relationship between geographical range to allozyme variability (Table 7). As the geographic range increases the total allelic diversity, the mean diversity within populations, and population differentiation increases (Table 10). Phacelia cookei's $\mathrm{H}_{\mathrm{t}}$ and $\mathrm{H}_{\mathrm{s}}$ are significantly lower than those reported for endemic plants by Hamrick (1983). Very low diversity at the population level indicated decreased evolutionary potential, which could pose a challenge for population persistence in the future.

The closest known relative to P. cookei is Phacelia suaveolens keckii (Walden 2010). Phacelia suaveolens keckii is an annual endemic to the Santa Ana Mountains that grows on volcanic soils in chaparral and Knobcone pine communities (Stephenson and Calcaron 1999). After fire has occurred Phacelia suaveolens keckii populations have been documented to increase in size (Stephenson and Calcaron 1999). Horner-Till (1982) 
documented the fire history of the area and speculated about the relationship between fire and $P$. cookei. Investigations into the role of fire and other sources of disturbance in $P$. cookei habitat should be conducted to determine if these are beneficial to population growth.

TABLE 10. The relationship of geographical range to allozyme variability.

\begin{tabular}{lccc}
\hline Geographical Region & Number of Studies & $\mathrm{H}_{\mathrm{t}}$ & $\mathrm{H}_{\mathrm{s}}$ \\
\hline Endemic & 10 & 0.275 & 0.208 \\
Narrow & 31 & 0.261 & 0.177 \\
Regional & 38 & 0.238 & 0.154 \\
Widespread & 43 & 0.380 & 0.293 \\
Phacelia cookei & 1 & 0.056 & 0.053 \\
\hline
\end{tabular}

Source: Adapted from HAMRICK, J. L. 1983. The distribution of genetic variation within and among natural plant populations. Pp. 335-348 in C. M. Schonewald-Cox, S. M. Chambers, B. MacBryde and W. L. Thomas (eds.), Genetics and Conservation. Benjamin-Commings, Menlo Park, CA. 


\section{CHAPTER V}

\section{CONCLUSION}

We identified a number of sites near existing populations of $P$. cookei with similar soil and habitat characteristics. Many of these sites appear to hold promise for restoration efforts with $P$. cookei. In addition, we established protocols for germinating seeds in the lab. Future studies should consider additional experiments investigating restoration by sowing seeds into suitable habitat, and the possible role of fire as a germination cue. Perhaps the main management challenge that we identified concerns low population genetic variation, which may limit the ability of this species to adapt to future environmental perturbations.

Phacelia cookei will require site-specific management because it is narrowly endemic, has small population sizes, and specialized life history requirements. Seeds should be harvested and used to create new populations in situ because $P$. cookei seeds germinate at low levels in the lab and are challenging to grow in a green house (M.E. Patterson, personal observation). The soil test for nutrients, texture, and $\mathrm{pH}$ did not show significant differences between sites with and without $P$. cookei, which suggests that endemism may not caused by edaphic limitations.

Since the Horner-Till study (1982) the number of known populations of P. cookei (40 reported) has decreased. These populations were not mapped, but a few (including the experimental populations used in this study) were documented in herbaria and likely 
include populations that Horner-Till studied. During surveys conducted 25-26 May, 2008, 10 populations were located (Schierenbeck and Edwards, unpublished data), including several that were not previously documented in herbaria. Habitat descriptions in Horner-Till (1982) indicate periodic fires, and firebreaks in the area contained populations of $P$. cookei. Future studies should consider examining the role of fire and other disturbance in creating and maintaining suitable habitat. 
REFERENCES 


\section{REFERENCES}

Alsos, I. G., T Engelskjon, And C. Brochmann. 2002. Conservation genetics and population history of Betula nana, Vaccinium uliginosum, and Campanula rotundifolia in the Arctic Archipelago of Svalbard. Artic, Antarctic, and Alpine Research 34:408-418.

Anotonovics, J. 1976. Limits to natural selection. Annuals of the Missouri Botanical Garden 63:224-247.

Barbour, M., T. Keeler-Wolf, AND A. A. Schoenherr. 2007. Terrestrial vegetation of California, Third Edition. Berkeley, CA, University of California Press.

BARRETT, S. C. H. AND J. R. KoHN. 1991. Genetic and evolutionary consequences of small population size in plants: Implications for conservations. Pp. 3-30 in D. A. Falk and K. E. Holsinger (eds.), Genetics and Conservation of Rare Plants. Oxford University Press, New York, NY.

Bourg, N. A., W. J. McSheA, AND D. E. GILl. 2005. Putting a cart before the search: Successful habitat prediction for a rare forest herb. Ecology 86:2793-4804.

BRAY, R. H. AND L. T. KURTZ. 1945. Determination of total, organic, and available forms of phosphorus in soils. Soil Science 59:39-46.

BROOK, B. W., N. S. SODHI, AND J. A. BRADSHAw. 2008. Synergies among extinction drivers under global change. Trends in Ecology and Evolution 23 453- 460.

BROYLES S. B. AND R. WyATT. 1990. Paternity analysis in a natural population of asclepias exaltat: Multiple paternity, functional gender, and the "pollen donation hypothesis.” Evolution 44 1454-1468.

Bundy, L. G. AND J. J. MEISINGER. 1994. Nitrogen availability indices. Pp 951-984 in R. W. Weaver, J. S. Angle, and P. S. Bottomly (eds.), Methods of Soil Analysis, Part 2: Microbiological and Biochemical Properties. Soil Science Society of America, Madison, WI.

Cabin, R. J., R. J. MitChell, And D. L. Marshall. 1998. Do surface plant and soil seed bank populations differ genetically? A multipopulation study of the desert mustard Lesquerella fendleri (Brassicaceae). American Journal of Botany 85:1098-1109. 
California Native Plant Society Vegetation Committee. 2007. California Native Plant Society-Rapid Vegetation Assessment Protocol. Available at: http://www.cnps.org/cnps/vegetation/pdf/rapid_assessment_protocol.pdf

Callaway, R. M. And L. R. WalKer. 1997. Competition and facilitation: A synthetic approach to interactions in plant communities. Ecology 78:1958-1965.

Cochrane, A., A. Kelly, K. Brown, And S. Cunneen. 2002. Relationships between seed germination requirements and ecophysiologiacal characteristics aid the recovery of threatened native plant species in western Australia. Ecological Management and Restoration 3:47-60.

ConNELL, J. H. 1978. Diversity in tropical rain forests and coral reefs. Science 199:13021310.

Constance, L. And L. HecKARD. 1970. Two new species of Phacelia (Hydrophyllaceae) from California. Brittonia 22:25-30.

Cowling, R. M, E. T. F Witkowski, A. V. Milewski, And K. R. NewBey. 1994. Taxonomic, edaphic and biological aspects of narrow plant endemism on matched sites in mediterranean South Africa and Australia. Journal of Biogeography 21:651664.

Del Castillo, R. F. 1994. Factors influencing the genetic structure of Phacelia dubia, a species with a seed bank and large fluctuations in population size. Heredity 72:446458.

Dolan, R. W., R. YAhr, AND E. S. MEnges. 2004. Population genetic structure in Nolina brittoniana (Agavaceae), a plant endemic to the central ridges of Florida. Southeastern Naturalist 3:25-36.

ELlSTRAND, N. C. AND D. R ElAM. 1993. Population genetic consequences of small population size: Implications for plant conservation. Annual Review of Ecology and Systematics 24:217-242.

FIEDLER, P. L. 1985. Heavy metal accumulation and the nature of the edaphic endemism in the genus Calochortus (Liliaceae). American Journal of Botany 72:1712-1718.

FILDES, R. A. AND H. HARRIS. 1966. Genetically determined variation of adenylate kinase in man. Nature 209:262-263.

Godt, M. J. W, B. R Johnson, And J. L. HAMricK. 1996. Genetic diversity and population size in four rare southern Appalachian plant species. Conservation Biology 10:796-805. 
GRIME, J. P. 1973. Competitive exclusion in herbaceous vegetation. Nature 242:344-347.

HAMRICK, J. L. 1983. The distribution of genetic variation within and among natural plant populations. Pp. 335-348 in C. M. Schonewald-Cox, S. M. Chambers, B. MacBryde and W. L. Thomas (eds.), Genetics and Conservation. Benjamin-Commings, Menlo Park, CA.

HAMriCK, J. L. AND M. J. W. GodT. 1989. Allozyme diversity in plant species. Pp. 43-63 in A. H. D. Brown, M. T. Clegg, A. L. Kahler, and B. S. Weir (eds.), Plant Population Genetics, Breeding, and Genetic Resources. Sinauer, Sunderland, MA.

Harrison, S., S. E. Meyer, And M. Stevens. In Press. Molecular genetic diversity and differentiation in clay Phacelia.

Hartl, D. L. And Clark A. G. 1989. Principles of population genetics, Second Edition. Sinauer Associates, Sunderland, MA.

Higgins, S. I, D. M. Richardson, R. M. Cowling, And T. H. TRinder-Smith. 1999. Predicting the landscape-scale distribution of alien plants and their threat to Plant diversity. Conservation Biology 13:303-313.

HoBBS, R. J. AND L. F. HuENNEKE. 1992. Disturbance, diversity, and invasion: Implications for conservation. Conservation Biology 6:324-337.

HORNER-TILL, S. 1982. Experimental insights on factors affecting the distribution of $P$. cookei Const. \& Heck., a narrow endemic. M.S. thesis. Utah State University, Logan, UT.

Huston, M. A. 2004. Management strategies for plant invasions: Manipulating productivity, disturbance, and competition. Diversity and Distributions 10:167-178.

KELLER, L. F. AND D. M. WALLER. 2002. Inbreeding effects in wild populations. Trends in Ecology \& Evolution 17: 230-241.

Klemmedson, J. O. And J. G. SMith. 1964. Cheatgrass (Bromus tectorum L.). Botanical Review 30:226-262.

KoCHANKOVA, J. AND B. MANDAK. 2009. How do population genetic parameters affect germination of the heterocarpic species Atriplex tatarica (Amaranthaceae)? Annals of Botany 103:1303-1313.

Kruckeberg, A. R. 1954. The ecology of serpentine soils. III. Plant species in relation to serpentine soils. Ecology 35:267-274. 
LAKON, G. 1949. The topographical tetrazolium method for determining the germination capacity of seeds. Plant Physiology 24:389-394.

MANCHENKO, G. P. 1994. Handbook of Detection of Enzymes on Electrophoretic Gels. CRC, Ann Arbor, MI.

MARKERT, C. L. AND I. FAULHABER. 1965. Lactate dehydrogenase isozyme patterns of fish. Journal of Experimental Zoology 159:319-332.

MAsON, H. L. 1946. The edaphic factor in narrow endemism. II. The geographic occurrence of plants of highly restricted patterns of distribution. Madroño 8:241257.

MCCue, K. A. AND T. P. HoltSFORD. 1998. Seed Bank Influences on genetic diversity in the rare annual Clarkia springvillensis (Ongraceae). American Journal of Botany 85:30-36.

MCINTYRE, S. AND S. LAVOREL. 1994. Predicting richness of native, rare, and exotic plants in response to habitat and disturbance variables across a variegated landscape. Conservation Biology 8:521-531.

MeizeL, S. AND G. L. MARKERT. 1967. Malate dehydrogenase isozymes of the marine snail Ilyanassa obsolete. Archives of Biochemistry and Biophysics 122:753-765.

MENGES, E. S. 1991. Seed germination percentage increases with population size in a fragmented prairie species. Conservation Biology 5:158-164.

MEYER, S. E. 2006. Strategies for seed propagation of native forbs. Pp. 3-9 in Riley, L.E.; R. K. Dumroese, T. D. Landis (tech. coords.), National Proceedings: Forest and Conservation Nursery Associations-2005, Proc. RMRS-P-43. Fort Collins, CO, U.S. Department of Agriculture, Forest Service, Rocky Mountain Research Station.

Myers, N., R. A. Mittermeier, C. G. Mittermeier, G. A. B. DA FonseCA, And J. Kent. 2000. Biodiversity hotspots for conservation priorities. Nature 403:853-858.

Millar, C. I. AND W. J. LibBy. 1989. Disneyland or native ecosystem: Genetics and the restorationists. Restoration and Management Notes 7:18-24.

MubareK, A. AND R. A. Olsen. 1976. Immiscible displacement of the soil solution by centrifugation. Soil Science Society of America Journal 40:329-331.

Myers, N., R. A. Mittermeier, C. G. Mittermeier, G. A. B. DA FonsecA, And J. Kent. 2000. Biodiversity hotspots for conservation priorities. Nature 403:853- 858. 
NEI, M. 1973. Analysis of gene diversity in subdivided populations. Proceedings of the National Academy of Science USA 70:3321-3323.

NEI, M. 1978. Estimation of average heterozygosity and genetic distance from a small number of individuals. Genetics 89:583-590.

Olmstead, R. G., R. K. JAnsen, K.-J. KiM, And S. J. WAGSTAFF. 2000. The phylogeny of the Asteridae s.l. based on chloroplast ndhF sequences. Molecular Phylogenetics and Evolution 6:96-112.

Pendergrass, K. L., P.M. Miller, J. B. Kauffman, And T. N. Kaye. 1999. The role of prescribed burning in maintenance of an endangered plant species, Lomatium bradshawii. Ecological Applications 9:1420-1429.

Preston, C. D. AND H. L. K. Whitehouse. 1986. The habitat of Lythrum hyssopifolia L. in Cambridgeshire, its only surviving English locality. Biological Conservation 35:41-62.

PugnaiRe, F. I. AND M. Lugue. 2001. Changes in plant interactions along a gradient of environmental stress. Oikos 93:42-49.

Reynolds, H. L., A. PACKer, J. D. BeVer, AND K. ClAy. 2003. Grassroots ecology: Plant-microbe-soil interactions and drivers of plant community structure and dynamics. Ecological Society of America 84:2281-2291.

SAWYer, J. O. AND T. KeEler-Wolf. 1995. A Manual of California Vegetation. California Native Plant Society, Sacramento, CA.

SIMBERLOFF, D. 1988. The contribution of population and community biology to conservation science. Annual Review of Ecology and Systematics 19:473-511.

Soltis, D. E. AND P. S. Soltis (eds.). 1989. Isozymes in Plant Biology. Dioscorides Press, Portland, OR.

Stephenson, J. R. AND G. M. CalCARONE. 1999. Southern California mountains and foothills assessment: Habitat and species conservation issues general technical report GTR-PSW-175. U.S. Department of Agriculture, Forest Service, Pacific Southwest Research Station, Albany, CA.

Thomas, G. W. 1984. Exchangeable cations. Pp. 159-165 in A. L. Page (ed.), Methods of Soil Analysis, Part 2: Chemical and Microbiological Properties. Soil Science Society of America, Madison, WI. 
USDA/NRCS [United State DePartment of AgRiCUlture, NATURAl REsOURCES CONSERVATION SERVICE]. National Soil Survey Handbook, Title 430-VI. United States Department of Agriculture, Washington, DC.

Van Vuuren, D. P., O. E. Sala, And H. M. Pereira. 2006. The future of vascular plant diversity under four global scenarios. Ecology and Society 11:25.

WALDEN, G. K. 2010. Phylogeny of infrageneric relationships within Phacelia (Boraginaceae) inferred from chloroplast sequence data. M. S. thesis. San Francisco State University, San Francisco, CA.

WeIR, B. S. (1990) Genetic Data Analysis. Sinauer Associates, Sunderland, MA.

WENDEL, J. F. AND N. F. WEEDEN. 1989. Visualization and interpretation of plant isozymes. Pp. 5-45 in D. E. Soltis and P. S. Soltis (eds.), Isozymes in Plant Biology. Dioscorides Press, Portland, OR.

Wilcove, D. S., D. Rothstein, J. Dubow, A. Philips, And E. Losos. 1998. Quantifying threats to imperiled species in the United States. Bioscience 48:607-615.

YeH, F. C., R. C.YAnG, AND T. BoyLE. 1999. Popgene version 1.31. Microsoft Windowsbased freeware for population genetic analysis. University of Alberta, Edmonton, Canada. 